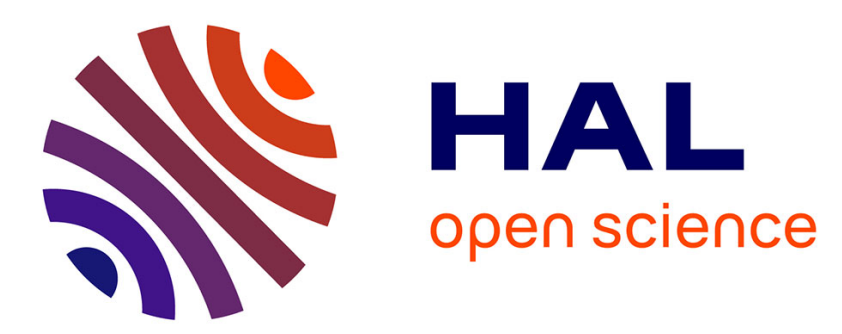

\title{
Factors affecting offspring body size in the solitary bee Osmia bicornis (Hymenoptera, Megachilidae)
}

\author{
Sabine Radmacher, Erhard Strohm
}

\section{To cite this version:}

Sabine Radmacher, Erhard Strohm. Factors affecting offspring body size in the solitary bee Osmia bicornis (Hymenoptera, Megachilidae). Apidologie, 2010, 41 (2), 10.1051/apido/2009064 . hal00892048

\section{HAL Id: hal-00892048 \\ https://hal.science/hal-00892048}

Submitted on 1 Jan 2010

HAL is a multi-disciplinary open access archive for the deposit and dissemination of scientific research documents, whether they are published or not. The documents may come from teaching and research institutions in France or abroad, or from public or private research centers.
L'archive ouverte pluridisciplinaire HAL, est destinée au dépôt et à la diffusion de documents scientifiques de niveau recherche, publiés ou non, émanant des établissements d'enseignement et de recherche français ou étrangers, des laboratoires publics ou privés. 


\title{
Factors affecting offspring body size in the solitary bee Osmia bicornis (Hymenoptera, Megachilidae)*
}

\author{
Sabine RADMACHER, Erhard STROHM \\ Institute of Zoology, University of Regensburg, 93040 Regensburg, Germany \\ Received 12 February 2009 - Revised 11 August 2009 - Accepted 15 August 2009
}

\begin{abstract}
Body size is related to fitness in many insects. In solitary bees offspring body size is largely determined by maternal provisions and microclimate. We studied the effect of quantity and quality of provisions and rearing temperatures $\left(20,25\right.$ and $\left.30^{\circ} \mathrm{C}\right)$ on body size in the Red Mason bee, Osmia bicornis. Cocoon weight increased with provision weight and decreased with increasing temperature. High temperature $\left(30^{\circ} \mathrm{C}\right)$ led to high mortality of larvae and smaller body size, partly due to incomplete consumption of the provisions. Diversity of pollen in the provisions was low, and most provisions primarily consisted of mainly oak and maple pollen. Pollen diversity did not affect cocoon weight and males provided with pure oak or pure maple pollen showed similar adult size. Our results suggest that the quantity of provisions and temperature, but not pollen quality influence the development of $O$. bicornis progeny and might affect population dynamics of this abundant European pollinator.
\end{abstract}

\section{Osmia bicornis / body size / pollen diversity / temperature}

\section{INTRODUCTION}

Solitary bees are important pollinators of both wild and crop plants (Batra, 1995; Freitas and Pereira, 2004). Due to the worldwide pollinator decline (Kearns et al., 1998), the economic importance of pollination services (Klein et al., 2007), and increasing knowledge about the role of the so-called "wild bees" in (crop) pollination (e.g. Winfree et al., 2007), the interest in conservation and management of wild bees has considerably increased. Thus, detailed knowledge is needed about the requirements for successful reproduction and population maintenance for at least in some model species.

Body size is related to fitness in many insects (Honěk, 1993). In solitary bees, several studies have shown advantages for larger individuals in foraging efficiency (Torchio and Tepedino, 1980), fecundity (Sugiura and

Corresponding author: S. Radmacher, sabine.radmacher@biologie.uni-regensburg.de * Manuscript editor: Jean-Noël Tasei
Maeta, 1989; Kim, 1997), nest usurpation (Tepedino and Torchio, 1994; Kim, 1997), and overwintering survival (Tepedino and Torchio, 1982; Bosch and Kemp, 2004). Thus, factors affecting offspring body size in solitary bees could play an important role in reproductive success and population dynamics. In solitary bees body size might be influenced by the amount of larval provisions, the quality of provisions, and temperature during development. Several studies have shown a strong correlation between the amount of provisions consumed by larvae and adult body size (e.g. Klostermeyer et al., 1973; Bosch and Vicens, 2002), whereas heritability for body size seems to be low (Tepedino et al., 1984).

Larval body size and performance might be influenced by the quality of pollen-nectar provisions as well. Pollen of different plant species differs in nutritional value (Roulston and Cane, 2000). Several studies have shown that different pollen types differentially influence larval growth and development in honey bees (e.g. Standifer, 1967), bumble bees (e.g. Tasei and Aupinel, 2008) and solitary bees 
(e.g. Levin and Haydak, 1957; Praz et al., 2008). Mixing of different pollen species could be advantageous, because it results in a better balance of nutritive substances and dilution of toxins (Bernays and Minkenberg, 1997; Tasei and Aupinel, 2008; Unsicker et al., 2008).

In addition to larval food, characteristics of the nesting site can affect offspring body size. Temperature is probably the most important abiotic ecological factor and the "temperaturesize rule" for ectotherms states that lower temperatures during development result in larger adult body size (e.g. Atkinson, 1994). Since nest sites of solitary bees probably vary in temperature regimes (due to variable solar irradiation and insulation), offspring body size is probably influenced by these differences.

In this study we investigated possible effects of (1) quantity and (2) quality of larval food as well as (3) temperature during development on body size of the Red Mason bee $O s$ mia bicornis (Linnaeus 1758, Hymenoptera, Megachilidae, formerly $O$. rufa L.). Based on empirical knowledge about other bees and herbivores, we predicted that the size of offspring bees will be positively correlated with both the amount and the diversity of pollen provisions (nectar was not included in the analysis due to its low amount in $O$. bicornis provisions). In brood cells provisioned with only one pollen species, larval performance might differ between pollen types due to differences in nutritional value. Furthermore, we tested the prediction that lower rearing temperatures result in larger body size of the bees.

\section{MATERIALS AND METHODS}

\subsection{Bees}

$O$. bicornis is one of the most abundant solitary bees in Central Europe (Westrich, 1989). The females of this univoltine, polylectic species fly from early April to mid-June and they accept a large range of pre-existing cavities where they build their (mostly) linear nests. Each nest consists of several brood cells that are provisioned with pollen and some nectar $(<4 \%$ of total provisions) and separated by loam partitions (Maddocks and Paulus, 1987; Strohm et al., 2002). Females attach a single egg onto the provisions of each brood cell. The larvae hatch, consume the provisions, spin a cocoon, pupate and undergo metamorphosis in late summer. They hibernate as adults inside their cocoons and emerge the next spring when temperature rises.

Brood cells were obtained from a population of $O$. bicornis nesting in trap nests in two observation huts near the Biocenter of the University of Würzburg, Germany. The vegetation surrounding the huts consisted of set-aside orchards (mainly apple trees and grassland), landscaped grounds (several tree species and lawn), and farmland (rape and cereal crops). Female bees readily accepted trap nests that were made of dense styrofoam covered with transparent polycarbonate lids that allowed continuous observation of nesting activity and brood development (for more details see Strohm et al., 2002). Between 8 May and 14 June 2006 we selected 26 completed nests with a total of 205 brood cells that contained eggs or newly hatched larvae which had not yet started feeding on the provisions. We brought them into the laboratory to determine the mass (quantity) and composition (quality) of pollen and to subject them to different temperature treatments (see Sect. 2.4).

\subsection{Pollen quantity}

Polycarbonate covers were carefully removed from the trap nests and brood cells were separated. The pollen loaf with the attached egg was removed with a custom made scoop of known weight. After weighing to the nearest $0.1 \mathrm{mg}$ (Mettler AE 160) the provision with egg/larva was carefully put back into the brood cell. Weighing the pollen loaf without the egg was not possible because detaching it from the provision would have harmed the egg or young larva. However, egg weight is largely the same for all brood cells; thus, the inclusion of egg weight should not have biased the results for provision weight. Brood cells were re-sealed with paper on the side and transparent foil on the top (fixed with adhesive tape) and subjected to different rearing temperature treatments (see Sect. 2.4). At the end of development, pollen remnants were weighed and the difference between the initial and final provision weight was considered to be the mass of pollen actually consumed.

\subsection{Pollen quality}

After removal of nest lids (see Sect. 2.2), samples of pollen were taken using a moistened needle that was used to puncture the provisions at 
five spots spread over the pollen loaf. After each puncture, pollen grains adhering to the needle were wiped onto a slide where they were immersed in Polyvinyllactophenol (PVL) and covered with a coverslip. To identify the bee-collected pollen in the provisions, a reference collection of pollen was prepared from all plants that flowered during the nesting activity of the bees within a radius of $500 \mathrm{~m}$ around the huts (107 plant species).

Pollen samples were viewed under a microscope (Leitz Laborlux S) with 500-fold total magnification and identified to plant family level based on comparisons with the reference collection. Since the pollen protein concentration - one of the most important factors influencing larval growth and body size in bees (e.g. Roulston and Cane, 2002) is highly conserved within plant families (Roulston et al., 2000), determination of pollen to plant family level seems to be sufficiently precise to investigate effects of pollen diversity on larval performance. The pollen grains of each family were counted over the whole field of vision at ten randomly selected positions per sample. As an approximation of pollen grain volume, we used the area (in pixels) covered by a pollen grain in the microscope view (photos taken with a Nikon Coolpix 4500 camera). We computed the percentage of the area covered by each pollen family and used these percentage values to calculate the Simpson Diversity Index (Begon et al., 1996) for each brood cell.

\subsection{Temperature treatments}

Brood cells were randomly allocated to three different rearing temperatures $-20^{\circ} \mathrm{C}(\mathrm{N}=68), 25^{\circ} \mathrm{C}$ $(\mathrm{N}=72)$, and $30^{\circ} \mathrm{C}(\mathrm{N}=65)-$ and stored in dark climate chambers (Ehret ATS 1373; Emmendingen, Germany; $\left.+/-1^{\circ} \mathrm{C}\right)$. For each group, the brood cells were placed into a plastic box $(20 \times 20 \times 6 \mathrm{~cm})$ which was covered with gauze to allow for ventilation and put into a cardboard box to prevent desiccation. For the $20^{\circ} \mathrm{C}$ and $25^{\circ} \mathrm{C}$ treatments, the brood cells were kept in the incubator for 13-17 weeks, at the end of which development was completed. However, in the $30{ }^{\circ} \mathrm{C}$-treatment we observed that most larvae consumed only part of their pollen provision and spun very early into very small cocoons. To avoid overly high mortality due to this obviously stressful temperature, we transferred these brood cells individually from $30{ }^{\circ} \mathrm{C}$ to $25^{\circ} \mathrm{C}$ immediately after cocoon spinning. This procedure still allowed the comparison of cocoon weights obtained at three different rearing temperatures but minimised further mortality for the $30{ }^{\circ} \mathrm{C}$ group. On 5 September 2006 , all brood cells were transferred to $10{ }^{\circ} \mathrm{C}$ to initiate diapause. The cocoons were weighed to the nearest $0.1 \mathrm{mg}$ at the same individual age (119122 days after oviposition) as a measure of adult body size. Then mortality and sex were determined by inspection of the bee after opening the apical end of the cocoon. Cocoons were immediately put back into their brood cells at $10{ }^{\circ} \mathrm{C}$.

\subsection{Data analyses}

Using an ANCOVA (SPSS 15.0), we analysed (1) the effects of pollen quantity, pollen diversity, and temperature on body size. Since the diversity indices were generally very low and could not be transformed to normal distribution, they were grouped into three different classes: low $(\mathrm{D}=$ 1.000-1.009; $\mathrm{N}=69$ ), middle $(\mathrm{D}=1.100-1.599$; $\mathrm{N}=57)$ and high $(\mathrm{D}=1.600-3.350 ; \mathrm{N}=57)$. Diversity class was used as a random factor in the analysis. (2) We tested for an effect of different single pollen species on growth by selecting cells containing mainly $(\geqslant 95 \%)$ a single pollen family. For this analysis, only male brood cells were used since the respective samples of females were too small for a reasonable analysis. (3) We analysed possible causes of pollen remnants taking into account the significant correlation (see Sect. 3.3) between the amount of provisions and the amount of pollen remnants. For all ANCOVAs, only brood cells in which progeny survived at least until sex determination were used $(\mathrm{N}=183)$. Furthermore, we compared the frequencies of brood cells with pollen remnants and mortality rates between temperature treatments using $\chi^{2}$-tests (BiAS 8.1).

\section{RESULTS}

\subsection{Pollen quantity and sex}

The ANCOVA showed strong effects of consumed pollen mass and sex on cocoon weight. Females were significantly heavier than males $(\mathrm{df}=1 ; \mathrm{F}=14.8 ; P=0.006$; Fig. 1) and body size was significantly positively correlated with the mass of consumed pollen (df $=1 ; \mathrm{F}=532.4 ; P<0.001 ;$ Fig. 2$)$. 


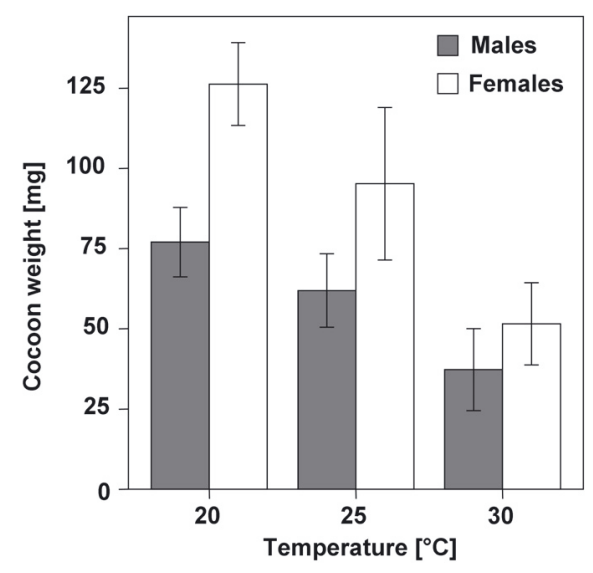

Figure 1. Cocoon weight (mean $\pm \mathrm{SD}$ ) of male (grey) and female (white) bee offspring reared at three different constant temperatures $\left(20{ }^{\circ} \mathrm{C}\right.$ : $\mathrm{N}_{\text {Males }}=47, \mathrm{~N}_{\text {Females }}=17 ; 25^{\circ} \mathrm{C}: \mathrm{N}_{\text {Males }}=58$, $\mathrm{N}_{\text {Females }}=9 ; 30^{\circ} \mathrm{C}: \mathrm{N}_{\text {Males }}=42, \mathrm{~N}_{\text {Females }}=10$ ).

\subsection{Pollen quality}

Despite the diverse pollen sources present in the surroundings of the nesting site, $O$. bicornis females used only a few plant species and/or families. For the main part of the nesting season they foraged primarily on oak (Fagaceae) and maple (Aceraceae), whereas towards the end of the flight season they mainly collected a mix of poppy (Papaveraceae, most probably Papaver rhoeas, $P$. dubium) and buttercup (Ranunculaceae, Ranunculus acer, $R$. auricomus, $R$. repens) pollen. We found pollen of many other plant families in the provisions (Brassicaceae, Fabaceae, Caryophyllaceae, Corylaceae, Salicaceae, Oleaceae, Asteraceae, Caprifoliaceae, Plantaginaceae), however, mostly only in trace amounts (i.e. $<5 \%$ ). In general, diversity indices of the pollen provisions were low (median $=1.22$; quartiles 1.03 and 1.75). In 71 brood cells ( $38.8 \%$ of the total examined), the provision consisted of mainly one pollen family ( $\geqslant 95 \%$ ): Fagaceae (most probably Quercus robur, 47 cells), Aceraceae (Acer campestre, A. platanoides, A. pseudo-platanus, 22 cells) and Rosaceae ( 2 cells). In 56 cells $(30.6 \%)$, one pollen family was dominant $(\geqslant 75 \%$; $<95 \%)$. In the remaining 56 cells no pollen family accounted for more than $75 \%$ and most did not contain considerable proportions of more than two pollen families. Pollen diversity (class) did not affect cocoon weight $(\mathrm{df}=$ $2 ; \mathrm{F}=4.3 ; P=0.787)$. There was no significant difference in the cocoon weight of males from 47 cells with $(\geqslant 95 \%)$ Fagaceae pollen and 22 cells with $(\geqslant 95 \%)$ Aceraceae pollen $(\mathrm{df}=1 ; \mathrm{F}=0.02 ; P=0.897)$.

\subsection{Temperature}

Mortality rates differed significantly between temperature treatments $\left(\chi^{2}=8.576\right.$; df $=2 ; P=0.0137)$. At $30{ }^{\circ} \mathrm{C}, 20 \%$ of bee offspring died, whereas the mortality rate at 20 and $25{ }^{\circ} \mathrm{C}$ was 5.9 and $6.9 \%$, respectively. Cocoon weight decreased significantly with increasing temperature $(\mathrm{df}=2 ; \mathrm{F}=74.0$; $P=0.001$; Fig. 1 ). This was due to two different effects: first, the frequency of brood cells with pollen remnants $\left(\chi^{2}=92.6\right.$; df $=2$; $P<0.00001)$ and the amount of pollen remnants $(\mathrm{df}=2 ; \mathrm{F}=115.2 ; P<0.001 ;$ Fig. 3$)$ increased with temperature (there was a significant effect of provision weight $(\mathrm{df}=1 ; \mathrm{F}=$ 48.9; $P<0.001)$ and $\operatorname{sex}(\mathrm{df}=1 ; \mathrm{F}=6.5$; $P=0.011)$ on the amount of pollen remnants, too). Second, for a given amount of consumed pollen the cocoon weight decreased with increasing temperature (Fig. 2). Thus, larvae consumed less food at higher temperatures and produced less body mass per unit of provisions at higher temperatures.

\section{DISCUSSION}

\subsection{Pollen quantity and sex}

We found a highly significant positive effect of consumed provision mass on body size, which is consistent with other studies on solitary bees and wasps (e.g. Strohm, 2000; Bosch and Vicens, 2002). Provision mass seems to be one of the most important factors determining offspring body size and is one reason for the often found sexual size dimorphism in mass provisioning solitary Hymenoptera (including $O$. bicornis), because females receive larger provisions than males (e.g. Maddocks and Paulus, 1987; Strohm, 2000; Strohm et al., 2002). 

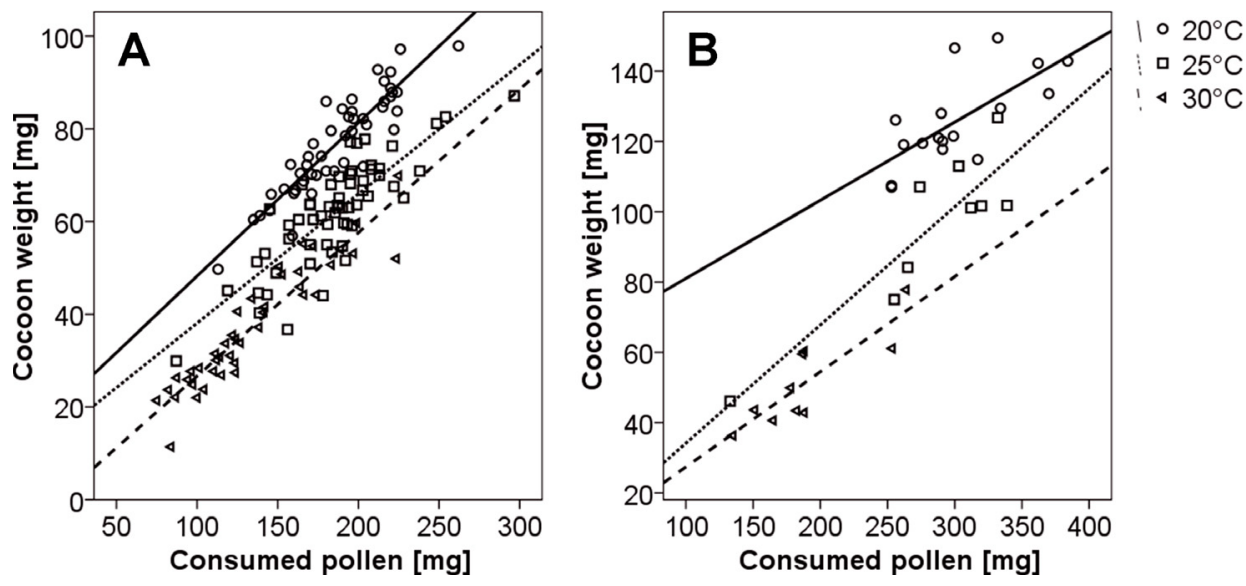

Figure 2. Correlations (Pearson) of cocoon weight and consumed pollen mass of A male and B female bee offspring reared at three different constant temperatures $\left(\mathrm{A}: \mathrm{N}_{20}{ }^{\circ} \mathrm{C}=47, \mathrm{R}^{2}=0.824 ; \mathrm{N}_{25}{ }^{\circ} \mathrm{C}=58\right.$, $\mathrm{R}^{2}=0.680 ; \mathrm{N}_{30}{ }^{\circ} \mathrm{C}=42, \mathrm{R}^{2}=0.879 ; \mathrm{B}: \mathrm{N}_{20}{ }^{\circ} \mathrm{C}=17, \mathrm{R}^{2}=0.499 ; \mathrm{N}_{25}{ }^{\circ} \mathrm{C}=9, \mathrm{R}^{2}=0.798 ; \mathrm{N}_{30}{ }^{\circ} \mathrm{C}=10$, $\mathrm{R}^{2}=0.736$ ).

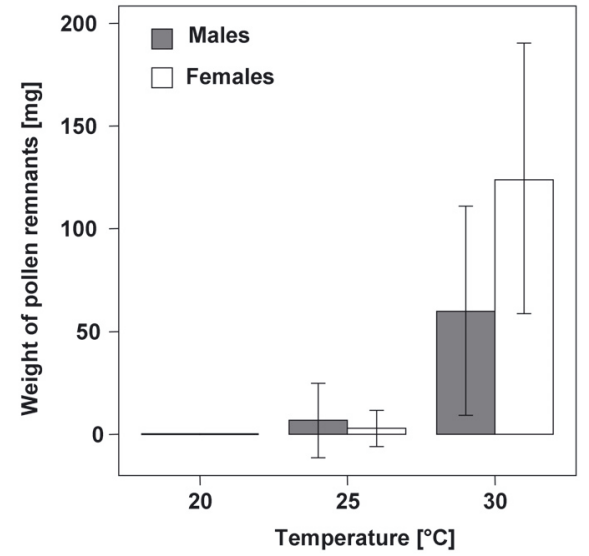

Figure 3. Mean weight $( \pm \mathrm{SD})$ of pollen remnants per brood cell of male (grey) and female (white) bee offspring reared at three different temperatures. All brood cells with surviving offspring (until cocoon stage) were included, regardless of whether they contained pollen remnants or not. In the $20^{\circ} \mathrm{C}$ treatment, no pollen remnants occurred $\left(20{ }^{\circ} \mathrm{C}\right.$ : $\mathrm{N}_{\text {Males }}=47, \mathrm{~N}_{\text {Females }}=17 ; 25^{\circ} \mathrm{C}: \mathrm{N}_{\text {Males }}=58$, $\mathrm{N}_{\text {Females }}=9 ; 30{ }^{\circ} \mathrm{C}: \mathrm{N}_{\text {Males }}=42, \mathrm{~N}_{\text {Females }}=10$ ).

\subsection{Pollen quality}

Pollen of different plant families can vary in nutrient composition (proportion of protein in particular) and certain pollen might lack some essential amino acids, lipids, vitamins or sterols, or might even contain toxins (e.g. Ranunculus spp.) that affect larval growth and performance (Levin and Haydak, 1957; Stanley and Linskens, 1974; Roulston and Cane, 2000). In addition, pollen species vary in digestibility for insect larvae so that efficiency of nutrient extraction and assimilation differs (Suárez-Cervera et al., 1994; Roulston and Cane, 2000). Several studies have shown advantages of mixed larval diets for herbivores (Bernays and Minkenberg, 1997; Unsicker et al., 2008) and bees (Stanley and Linskens, 1974; Tasei and Aupinel, 2008). In contrast to these studies, we found no effect of pollen diversity on body size of $\mathrm{O}$. bicornis. However, the generally low diversity in the provisions could have precluded the detection of such an effect. Thus, the question whether pollen diversity could influence larval growth cannot be reliably answered by our study. A manipulative approach that employs a substitution of the natural provision with pollen mixtures of different diversity could help to clarify this question. Furthermore, we recorded only offspring size; development times and, in particular, adult performance could be relevant measures as well.

Despite a wide variety of available pollen types during the nesting period, the females 
created provisions containing mainly only one or two pollen families and only small trace amounts of others. Such a pattern has frequently been reported for this and other polylectic bee species (e.g. Raw, 1974; Cripps and Rust, 1989; Müller, 1996; Quiroz-Garcia et al., 2001). A strong preference for oak and maple is consistent with other studies on solitary bees, including $O$. bicornis (e.g. Chambers, 1945; Tasei, 1973; Raw, 1974; Kraemer and Favi, 2005). While maple produces pollen and nectar, oak is wind-pollinated and offers large quantities of pollen, but no nectar. Since bee females need nectar in addition to pollen, females that collect oak pollen have to visit other plant species for nectar. As they do so, they probably pick up small quantities of pollen, which might explain the trace amounts of some pollen families in the provisions.

The predominance of low-diversityprovisions under natural conditions suggests that $O$. bicornis females specialize temporarily (and locally) on one or two plant species with high pollen availability to maximize the collected pollen mass per time unit. This behaviour reduces the provisioning time for a brood cell and is probably adaptive due to two not-mutually exclusive reasons. First, weather conditions are rather unstable in spring; thus, the available pollen should be exploited as fast as possible. Second, the risk of open-cell parasitism during the females' absence from the nest (Goodell, 2003; Seidelmann, 2006) can be reduced. It seems plausible that females face a trade-off between diversity and amount of provisions for their offspring since the collection of a given amount of pollen probably takes longer the more plant species are visited. Since we found no effect of pollen diversity on developmental success (but see above), O. bicornis females should maximize pollen mass without taking pollen diversity into account.

Some studies demonstrated differential growth and/or mortality for bees grown on single pollen species due to their different nutrient compositions (e.g. Levin and Haydak, 1957; Roulston and Cane, 2002; Praz et al., 2008). The protein content of the consumed pollen is generally considered to be the most important factor influencing bee growth (e.g. Roulston and Cane, 2000), albeit not the only one (see e.g. Levin and Haydak, 1957; Stanley and Linskens, 1974). Roulston et al. (2000) pointed out that pollen of 377 plant species from 93 families ranges from $2.5 \%$ to $61 \%$ in protein content (most values were within $15-40 \%)$. The reported pollen protein contents for different Acer-species (see also McLellan, 1977) were 34.75 to $45.2 \%$, nine Quercusspecies ranged from 30.6 to $41.5 \%$ (Roulston et al., 2000). Regarding a possible deviation of up to $5 \%$ in pollen protein content due to different environmental conditions (Stanley and Linskens, 1974), maple and oak pollen seem to be similar in protein content. This could explain the lack of differences in cocoon weight of larvae reared on these pollen families in our study. While Acer spp. are insect-pollinated plant species, Quercus spp. are usually wind-pollinated. Thus, our results represent an example for equal bee growth on pollen of zoophilous and anemophilous plants.

Though there is no clear evidence that bees prefer to collect protein-rich pollen (Roulston et al., 2000), the females in this study collected pollen families with a relatively high protein content $(>30 \%)$. After the main nesting season when the maple and oak bloom was over, provisions contained mainly a mix of poppy (Papaveraceae) and buttercup (Ranunculaceae) pollen. While poppy pollen has a protein content of 43.1 to $45.3 \%$, McLellan (1977) reported a value of only $19.4 \%$ for buttercup. Because of these differences, it would have been very interesting to include bee growth on pollen of these two pollen families. Moreover, Ranunculaceae pollen might have negative effects on larval development since it is suspected to contain toxic substances (e.g. Stanley and Linskens, 1974).

\subsection{Temperature}

In agreement with the general temperaturesize rule for ectotherms (Atkinson, 1994), we found that cocoon weight decreased with increasing temperature. The proximate as well as the ultimate causes for this phenomenon are still ambiguous and general explanations 
may not exist (Angilletta and Dunham, 2003; Walters and Hassall, 2006). Karl and Fischer (2008) reported that the copper butterfly $L y$ caena tityrus attained higher body weight at lower temperatures by behavioural as well as physiological mechanisms: Caterpillars consumed less food and had a lower efficiency in converting ingested food into body mass at higher temperatures. Consistent with these results, the larvae of the $O$. bicornis showed a decreased food intake at higher temperatures (behavioural mechanism). In particular at $30^{\circ} \mathrm{C}$, larvae left considerable amounts of their provisions unconsumed and started cocoon spinning early, resulting in (very) small body sizes. However, we also observed a reduced cocoon weight per unit of consumed provisions at higher temperatures (Fig. 2). This suggests that there is also a physiological mechanism that causes a reduction in growth efficiency and size. We can only speculate on possible explanations: developmental rate might be more accelerated than growth rate or the critical weight for differentiation might be reduced at higher temperatures (Ratte, 1984). However, because we did not record the duration of developmental stages, no information about developmental rates of the three temperature groups are available. Moreover, we cannot exclude a possible negative effect of low humidity and/or desiccation of provisions at higher temperatures since relative humidity could not be precisely controlled in the climate chambers.

In contrast to honeybee brood which is reared at a constant temperature of about $35^{\circ} \mathrm{C}$ (e.g. Jones et al., 2004), constant $30^{\circ} \mathrm{C}$ seems to be too high for the $O$. bicornis larvae and results in both high mortality and a very small adult body size. We suppose that such small adults were probably not able to survive until spring due to insufficient energy reserves for overwintering (see Bosch and Kemp, 2004).

\subsection{Conclusions}

Our results suggest that the amount of consumed pollen plays a major role in determining offspring body size and might thus affect fitness in the Red Mason bee Osmia bicor- nis, whereas pollen diversity has no effect on larval growth. Therefore, the presence of at least a few plant species with abundant pollen seems to be more important for the maintenance of $O$. bicornis populations than a diverse spectrum of plant species around nesting sites. Furthermore, we provide clear evidence that $O$. bicornis follows the temperature-size rule in development (decreasing body size with increasing temperature), and that constant temperatures above $25^{\circ} \mathrm{C}$ can negatively affect bee offspring. Future studies of growth on provisions of different pollen diversity, growth on different single pollen species, and the effect of different constant and fluctuating temperatures on bee growth and fitness are necessary to elucidate the requirements for pollen sources and nesting sites of this important European pollinator.

Facteurs affectant la taille corporelle de la progéniture de l'abeille solitaire Osmia bicornis (Hymenoptera : Megachilidae).

\section{Osmia bicornis / taille corporelle/ diversité du pollen / température}

Zusammenfassung - Faktoren, die die Körpergröße des Nachwuchses der solitären Biene Osmia bicornis (Hymenoptera, Megachilidae) beeinflussen. Die Körpergröße hat bei vielen Insekten Auswirkungen auf die Fitness. Bei solitären Bienen wird die Größe des Nachwuchses hauptsächlich durch den von der Mutter zur Verfügung gestellten Proviant und das Mikroklima bestimmt. Wir untersuchten den Einfluss von Quantität und Qualität (insbesondere Pollendiversität) des Larvenproviants und verschiedener konstanter Aufzuchtstemperaturen $\left(20,25\right.$ und $\left.30{ }^{\circ} \mathrm{C}\right)$ auf die Körpergröße der Roten Mauerbiene Osmia bicornis, einer wichtigen Europäischen Bestäuberart. Wir separierten Brutzellen mit Eiern oder jungen Larven aus Styrodur ${ }^{\circledR}$-Nisthilfen, entnahmen Pollenproben und verteilten die Brutzellen zufällig auf drei Gruppen, die sich bei verschiedenen Temperaturen in dunklen Brutschränken entwickelten. Nach abgeschlossener Metamorphose wurden die Kokons und Pollenreste gewogen sowie das Geschlecht der Bienen bestimmt. Der Pollen in den entnommenen Proben wurde bis auf die Ebene der Pflanzenfamilie bestimmt und für jede Brutzelle wurde ein Diversitäts-Index berechnet.

Generell war die Pollendiversität in den Brutzellen gering. Die Pollenkuchen bestanden hauptsächlich aus Pollen von ein oder zwei Familien, meist Ahorn und Eiche. Die Pollendiversität zeigte keinen 
Einfluss auf das Kokongewicht. Männchen, die als Larvenproviant fast reinen Ahorn- oder Eichenpollen zur Verfügung hatten, erreichten eine ähnliche Adultgröße. Im Gegensatz dazu hatten das Geschlecht, die Pollenmenge und die Aufzuchtstemperatur signifikante Auswirkungen auf das Kokongewicht: Weibchen waren schwerer/größer als Männchen und das Kokongewicht stieg mit zunehmender Proviantmenge und sank mit zunehmender Aufzuchtstemperatur (Abb. 1 und 2). Bei einer Entwicklungstemperatur von $30{ }^{\circ} \mathrm{C}$ wurde in den meisten Brutzellen der Proviant nicht vollständig konsumiert (75 \%, siehe auch Abb. 3) und die Mortalität war sehr hoch. Demzufolge könnten moderat hohe Temperaturen die Entwicklung von $O$. bicornis negativ beeinflussen.

Während sich ein Mischnahrung von mehreren Pflanzenarten bei einigen Herbivoren und anderen Bienenarten als vorteilhaft erwiesen hat, deuten das Fehlen eines Effekts der Pollendiversität auf das Kokongewicht sowie die starke Präferenz der Bienenweibchen für wenige Pflanzenarten mit hoher Blütendichte darauf hin, dass die Pollendiversität weniger relevant für das Larvenwachstum bei $O$. bicornis ist. Die Pollenmenge scheint hingegen die Hauptrolle in der Determination der Körpergröße der Nachkommen zu spielen und könnte somit auch deren Fitness beeinflussen. Daraus folgern wir, dass für O.bicornis-Populationen in einem Habitat wenige Pflanzenarten mit einem hohen Pollenangebot wichtiger sind als ein diverses Pflanzenspektrum.

\section{Osmia bicornis / Körpergröße / Pollendiversität / Temperatur}

\section{REFERENCES}

Angilletta M.J. Jr., Dunham A.E. (2003) The temperature-size rule in ectotherms: Simple evolutionary explanations may not be general, Am. Nat. 162, 332-342.

Atkinson D. (1994) Temperature and organism size - a biological law for ectotherms? Adv. Ecol. Res. 25, $1-58$.

Batra S.W.T. (1995) Bees and pollination in our changing environment, Apidologie 26, 361-370.

Begon M., Harper J.L., Townsend C.R. (1996) Ecology, Blackwell Science, Malden, Oxford, Melbourne, Berlin.

Bernays E.A., Minkenberg O.P.J.M. (1997) Insect herbivores: Different reasons for being a generalist, Ecology 78, 1157-1169.

Bosch J., Kemp W.P. (2004) Effect of pre-wintering and wintering temperature regimes on weight loss, survival, and emergence time in the mason bee Osmia cornuta (Hymenoptera: Megachilidae), Apidologie 35, 469-479.
Bosch J., Vicens N. (2002) Body size as an estimator of production costs in a solitary bee, Ecol. Entomol. 27, 129-137.

Chambers V.H. (1945) British bees and wind-borne pollen, Nature 155, 145-145.

Cripps C., Rust R.W. (1989) Pollen preferences of seven Osmia species (Hymenoptera: Megachilidae), Environ. Entomol. 18, 133-138.

Freitas B.M., Pereira J.O.P. (2004) Solitary bees: Conservation, rearing and management for pollination, Universidade Federal do Ceará, Ceará, Brazil.

Goodell K. (2003) Food availability affects Osmia pumila (Hymenoptera: Megachilidae) foraging, reproduction, and brood parasitism, Oecologia 134, 518-527.

Honěk A. (1993) Intraspecific variation in body size and fecundity in insects: a general relationship, Oikos 66, 483-492.

Jones J.C., Myerscough M.R., Graham S., Oldroyd B.P. (2004) Honey bee nest thermoregulation: diversity promotes stability, Science 305, 402-404.

Karl I., Fischer K. (2008) Why get big in the cold? Towards a solution to a life-history puzzle, Oecologia 155, 215-225.

Kearns C.A., Inouye D.W., Waser N.M. (1998) Endangered mutualisms: The conservation of plant-pollinator interactions, Annu. Rev. Ecol. Syst. 29, 83-112.

Kim J.-Y. (1997) Female size and fitness in the leafcutter bee Megachile apicalis, Ecol. Entomol. 22, 275-282.

Klein A.-M., Vaissière B.E., Cane J.H., SteffanDewenter I., Cunningham S.A., Kremen C., Tscharntke T. (2007) Importance of pollinators in changing landscapes for world crops, Proc. R. Soc. London B 274, 303-313.

Klostermeyer E.C., Mech S.J., Rasmussen W.B. (1973) Sex and weight of Megachile rotundata (Hymenoptera: Megachilidae) progeny associated with provision weights, J. Kansas Entomol. Soc. 46, 537-548.

Kraemer M.E., Favi F.D. (2005) Flower phenology and pollen choice of Osmia lignaria (Hymenoptera: Megachilidae) in Central Virginia, Environ. Entomol. 34, 1593-1605.

Levin M.D., Haydak M.H. (1957) Comparative value of different pollens in the nutrition of Osmia lignaria, Bee World 38, 221-226.

Maddocks R., Paulus H.F. (1987) Quantitative Aspekte der Brutbiologie von Osmia rufa L. und Osmia cornuta Latr. (Hymenoptera: Megachilidae): Eine vergleichende Untersuchung zu Mechanismen der Konkurrenzminderung zweier nahverwandter Bienenarten, Zool. Jahrb. Abt. Syst. Ökol. Geogr. Tiere 114, 15-44.

McLellan A.R. (1977) Minerals, carbohydrates and amino acids of pollens from some woody and herbaceous plants, Ann. Bot. 41, 1225-1232. 
Müller A. (1996) Host-plant specialization in western palearctic anthidine bees (Hymenoptera: Apoidea: Megachilidae), Ecol. Monogr. 66, 235-257.

Praz C.J., Müller A., Dorn S. (2008) Specialized bees fail to develop on non-host pollen: Do plants chemically protect their pollen? Ecology 89, 795804.

Quiroz-Garcia D.L., Martinez-Hernandez E., PalaciosChavez R., Galindo-Miranda N.E. (2001) Nest provisions and pollen foraging in three species of solitary bees (Hymenoptera:Apidae) from Jalisco, Mexico, J. Kansas Entomol. Soc. 74, 61-69.

Ratte H.T. (1984) Temperature and insect development, in: Hoffmann K.H. (Ed.), Environmental physiology and biochemistry of insects, Springer, Berlin, Heidelberg.

Raw A. (1974) Pollen preferences of three Osmia species (Hymenoptera), Oikos 25, 54-60.

Roulston T.H., Cane J.H. (2000) Pollen nutritional content and digestibility for animals, Plant Syst. Evol. 222, 187-209.

Roulston T.H., Cane J.H. (2002) The effect of pollen protein concentration on body size in the sweat bee Lasioglossum zephyrum (Hymenoptera: Apiformes), Evol. Ecol. 16, 49-65.

Roulston T.H., Cane J.H., Buchmann S.L. (2000) What governs protein content of pollen: pollinator preferences, pollen-pistil interactions, or phylogeny? Ecol. Monogr. 70, 617-643.

Seidelmann K. (2006) Open-cell parasitism shapes maternal investment patterns in the Red Mason bee Osmia rufa, Behav. Ecol. 17, 839-848.

Standifer L.N. (1967) A comparison of protein quality of pollens for growth-stimulation of hypopharyngeal glands and longevity of honey bees Apis mellifera L (Hymenoptera - Apidae), Insect. Soc. 14, 415-426.

Stanley R.G., Linskens H.F. (1974) Pollen - biology, biochemistry, management, Springer, Berlin, Heidelberg, New York.

Strohm E. (2000) Factors affecting body size and fat content in a digger wasp, Oecologia 123, 184-191.

Strohm E., Daniels H., Warmers C., Stoll C. (2002) Nest provisioning and a possible cost of reproduction in the megachilid bee Osmia rufa studied by a new observation method, Ethol. Ecol. Evol. 14, $255-268$.
Suárez-Cervera M., Marquez J., Bosch J., SeoaneCamba J. (1994) An ultrastructural study of pollen grains consumed by larvae of Osmia bees (Hymenoptera, Megachilidae), Grana 33, 191204.

Sugiura N., Maeta Y. (1989) Parental investment and offspring sex ratio in a solitary mason bee, Osmia cornifrons (Radoszkowski) (Hymenoptera, Megachilidae), Jpn J. Entomol. 57, 861-875.

Tasei J.-N. (1973) Le comportement de nidification chez Osmia (Osmia) cornuta Latr. et Osmia (Osmia) rufa L. (Hymenoptera Megachilidae), Apidologie 4, 195-225.

Tasei J.-N., Aupinel P. (2008) Nutritive value of 15 single pollens and pollen mixes tested on larvae produced by bumblebee workers (Bombus terrestris, Hymenoptera: Apidae), Apidologie 39, 397-409.

Tepedino V.J., Torchio P.F. (1982) Phenotypic variability in nesting success among Osmia lignaria propinqua females in a glasshouse environment (Hymenoptera: Megachilidae), Ecol. Entomol. 7, 453-462.

Tepedino V.J., Torchio P.F. (1994) Founding and usurping: Equally efficient paths to nesting success in Osmia lignaria propinqua (Hymenoptera: Megachilidae), Ann. Entomol. Soc. Am. 87, 946953.

Tepedino V.J., Thompson R., Torchio P.F. (1984) Heritability for size in the Megachilid bee Osmia lignaria propinqua Cresson, Apidologie 15, 8388.

Torchio P.F., Tepedino V.J. (1980) Sex ratio, body size and seasonality in a solitary bee, Osmia lignaria propinqua Cresson (Hymenoptera: Megachilidae), Evolution 34, 993-1003.

Unsicker S., Oswald A., Köhler G., Weisser W. (2008) Complementarity effects through dietary mixing enhance the performance of a generalist insect herbivore, Oecologia 156, 313-324.

Walters R.J., Hassall M. (2006) The temperature-size rule in ectotherms: May a general explanation exist after all? Am. Nat. 167, 510-523.

Westrich P. (1989) Die Wildbienen BadenWürttembergs (Band 1 \& 2), Ulmer, Stuttgart.

Winfree R., Williams N.M., Dushoff J., Kremen C. (2007) Native bees provide insurance against ongoing honey bee losses, Ecol. Lett. 10, 11051113 . 